\title{
PENYULUHAN DAN WORKSHOP OBAT NYAMUK SINTETIS DAN ALAMI SEBAGAI TINDAKAN PENCEGAHAN DBD
}

\section{SEMINAR AND WORKSHOP OF SYNTHETIC AND NATURAL MOSQUITOES REPELLENT AS DHF PREVENTION ACTIONIN WEST}

\author{
${ }^{1)}$ Agnes Anania Triavika Sahamastuti, ${ }^{2}$ Elsabda Siratan, ${ }^{3)}$ Theodore Ebenezer \\ Leonard, ${ }^{3)}$ Gisella Edny Tjugianto, ${ }^{4)}$ Leonny Yulita Hartiadi, ${ }^{5}$ Istiqomah Agusta \\ ${ }^{1,2,3,4)}$ Program Studi Farmasi, Fakultas Bio Sains, Indonesia International Institute for Life Science, \\ Indonesia \\ ${ }^{5)}$ Program Studi Biomedis dan Rekayasa Hayati, Fakultas Bio Sains, Indonesia International Institute \\ for Life Science, Indonesia \\ Jalan Pulomas Barat kav 88, Jakarta Timur, 13210. \\ Email: agnes.sahamastuti@i3l.ac.id
}

\begin{abstract}
ABSTRAK
Selama bulan Januari-Februari 2016, Jakarta Timur menduduki peringkat kedua dalam jumlah penderita DBD. Hal ini diperkirakan karena kurangnya partisipasi masyarakat dalam pemberantasan sarang nyamuk dan menjaga sanitasi. Hingga saat ini, masyarakat umum menggunakan obat pengusir nyamuk untuk menghindari gigitan nyamuk. Namun penggunaan pengusir nyamuk sintetis dengan cara yang salah dan dalam jangka waktu lama dapat berdampak buruk terhadap kesehatan. Kegiatan Pengabdian Masyarakat ini bertujuan untuk meningkatkan pengetahuan masyarakat mengenai bahaya penggunaan obat pengusir nyamuk sintetis dan pemberian solusi melalui bahan alamiah berkhasiat mengusir nyamuk. Kegiatan ini dilakukan di wilayah RW 11, Pulomas Barat, DKI Jakarta dengan melibatkan kelompok ibu PKK dan Jumantik (Jumat Bebas Jentik) dan dihadiri oleh 37 orang partisipan. Hasil evaluasi menunjukkan bahwa pengetahuan para partisipan mengenai bahaya obat nyamuk sintetis beserta cara pembuatan obat nyamuk alami meningkat setelah penyuluhan. Data mengenai tingkat penggunaan obat pengusir nyamuk di daerah warga juga berhasil diperoleh. Para partisipan dilatih membuat lotion pengusir nyamuk dari bahan alami diakhir kegiatan. Kegiatan ini diharapkan dapat meningkatkan kesadaran masyarakat untuk berpartisipasi aktif dalam menurunkan angka kejadian penyakit DBD dengan memanfaatkan bahan-bahan alami yang terjangkau dan mudah diperoleh.
\end{abstract}

Kata kunci: Demam Berdarah Dengue; Pencegahan; Obat Nyamuk Sintetis; Obat Nyamuk Alami

\begin{abstract}
During January-February 2016, East Jakarta was ranked as the second-highest number of DHF patients, due to lack of community participation in eradicating mosquito nests and maintaining sanitation. The general community mostly use mosquito repellent to avoid mosquito bites. However, misuse and over-use of synthetic mosquito repellent could negatively impact health. This Community Service activity aims to increase public knowledge of the dangers of using synthetic mosquito repellent and provide solution through the use of herbs that can repel mosquitoes. The action was carried out in RW 11 area, West Pulomas, DKI Jakarta by involving PKK group and Jumantik (Jumat bebas jentik) and was attended by 37 participants. Results showed that the participants' knowledge about the dangers of synthetic mosquito repellent along with method of producing natural repellent increased after counseling. Data on the usage level of mosquito repellent in the residents' area were also obtained. This activity is expected to increase public awareness to actively participate in reducing the incidence of DHF by utilizing natural materials that are affordable and easily obtainable.
\end{abstract}

Keywords: Dengue Hemorrhagic Fever; Prevention; Synthetic Mosquito Repellent; Natural Mosquito Repellent 
Agnes Anania Triavika Sahamastuti, Elsabda Siratan, Theodore Ebenezer Leonard, Gisella Edny Tjugianto, Leonny Yulita Hartiadi, Istiqomah Agusta

Penyuluhan dan Workshop Obat Nyamuk Sintetis dan Alami Sebagai Tindakan Pencegahan DBD

Submitted : 17 Juni $2019 \quad$ Revision : 1 Juli 2019 Accepted : 20 Juli 2019

\section{PENDAHULUAN}

Demam Berdarah Dengue, atau biasa disebut DBD, merupakan penyakit yang umum terjadi pada daerah beriklim tropis, disebabkan oleh virus yang dikandung oleh nyamuk Aedes Aegypti betina. Umumnya, nyamuk ini menggigit pada saat pagi dan senja hari (Godfree R., 2014). Setiap tahun, penyakit ini menyerang Indonesia dengan tingkat kejadian yang cukup tinggi, yakni mencapai 198 dalam 100.000 penduduk dengan tingkat kematian sebesar $0.07 \%$. Pada awal Februari 2016, jumlah kasus DBD di Jakarta Timur tercatat sebanyak 328 kasus dengan urutan kedua setelah Jakarta Selatan (Kompas.com, 2016). Dinas Kesehatan DKI Jakarta mencatat tingkat penderita penyakit DBD di Jakarta pada tahun 2016 sudah mendekati Kejadian Luar Biasa (KLB), dengan peningkatan $30 \%$ dari tahun sebelumnya dan kasus DBD meningkat 2 kali lipat menjadi 611 kasus hanya dalam rentang waktu 2 pekan (Merdeka, 2016). Kasus DBD umumnya meningkat saat musim hujan (rentang September hingga Februari), dikarenakan tingginya curah hujan menyebabkan terbentuknya genangan-genangan air. Adanya genangan air pada sisa kaleng bekas, bak mandi, ban bekas dan lainnya menyebabkan nyamuk Aedes Aegypti berkembangbiak pesat. Nyamuk ini menyukai genangan air yang bersih dan tidak kontak langsung dengan tanah (Hendra dan Mila, 2004). Daerah Pulomas, Jakarta Timur juga dekat dengan kali Sunter, dimana banyak timbunan sampah yang menumpuk sehingga air kali tidak dapat mengalir dengan baik dan menciptakan genangan air tempat berkembang biak nyamuk. Kondisi jalanan yang tidak rata juga memiliki potensi untuk menciptakan genangan air di jalan saat curah hujan tinggi.
Dalam rangka antisipasi menekan jumlah kasus DBD di kawasan Pulomas Barat, Kelurahan Kayu Putih pada setiap hari Jumat di minggu ketiga, warga RW 11 Pulomas Barat dan puskesmas setempat melakukan gerakan Jumantik (Jumat Bebas Jentik). Kegiatan ini mencakup skrining jentik nyamuk di sejumlah rumah perwakilan warga. Disamping gerakan ini, pemerintah juga ikut turut serta memberantas sarang nyamuk dengan metode $3 \mathrm{M}$ plus, yakni Menguras, Menutup tempat penampungan air, dan Memanfaatkan kembali barang bekas untuk mencegah perkembangbiakan nyamuk Aedes Aegypti. Untuk kegiatan plus, meliputi penggunaan obat nyamuk, penggunaan kelambu tidur, pemeliharaan ikan pemangsa jentik nyamuk, penanaman tanaman pengusir nyamuk, penaburan bubuk larvasida pada tempat penampungan air, pengaturan cahaya dan ventilasi dalam rumah, dan tidak menggantung pakaian dalam rumah (Suharmiati, 2007). Namun, kegiatan ini dinilai tidak cukup efektif, dilihat dari naiknya angka kasus DBD dari tahun 2011 sampai tahun 2016 (Kementerian Kesehatan Republik Indonesia, 2016). Begitu juga untuk data dari kecamatan Pulo Gadung untuk sepanjang tahun 2015 dan bulan Januari-Februari 2016, ditemukan sebanyak 221 penduduk terjangkit DBD dan 1 korban meninggal dunia, dilansir dari Jakarta Open Data (data.jakarta.go.id).

Sebuah studi di Kabupaten Indramayu, Jawa Barat, melaporkan keefektifan obat pengusir nyamuk untuk menurunkan jumlah kasus DBD (Munif, Musadad, dan Kasnodihardjo, 2013). Masyarakat memiliki kecenderungan untuk memilih obat pengusir nyamuk dalam bentuk lotion atau spray dikarenakan murah dan mudah 
Agnes Anania Triavika Sahamastuti, Elsabda Siratan, Theodore Ebenezer Leonard, Gisella Edny Tjugianto, Leonny Yulita Hartiadi, Istiqomah Agusta

Penyuluhan dan Workshop Obat Nyamuk Sintetis dan Alami Sebagai Tindakan Pencegahan DBD

penggunaannya (Wahyono and Oktarinda, 2016). Obat pengusir nyamuk di pasaran umumnya mengandung 3 zat aktif yang memiliki efek samping terhadap kesehatan, yaitu (1) DEET (dietyltoluamide) yang dapat menimbulkan kerusakan otak dan kulit (Briassoulis et al., 2001; Goodyer dan Behrens, 1998; Robbins dan Cherniack, 1986), (2) propoxur, yang berpotensi menyebabkan mutasi gen pada sel darah putih jika digunakan secara terus menerus dengan dosis tinggi (Briassoulis et al., 2001; Cid, Loria, dan Matos,1990; Vandekar, Plestina, dan Wilhelm, 1971), dan (3) DDVP (dichlorvos) yang dapat memicu kerusakan sel saraf dan gejala keracunan pada dosis tinggi (Agency, 2000; Binukumar dan Gill, 2010). Untuk itu, diperlukan alternatif lain pengganti obat nyamuk sintetis yang aman, mudah diperoleh dan efektif digunakan untuk mengusir nyamuk. Dari hasil penelusuran, diperoleh bahwa lotion berbasis herbal alami yakni sereh, kulit jeruk, dan daun mint diyakini dapat digunakan sebagai obat pengusir nyamuk yang ampuh menggantikan obat pengusir nyamuk sintetis.

Minyak esensial sereh mengandung myrcene yang bertindak sebagai relaksan dalam mengurangi rasa sakit kepala, kejang-kejang, kram otot, serta melegakan sistem saraf pusat dan insomnia (Chillemi et al., 2017). Sementara citronella pada minyak esensial sereh dikenal sangat efektif sebagai pengusir nyamuk alami. Dilaporkan bahwa 5 - 10\% konsentrasi citronella pada kulit memiliki efektivitas yang sama dengan obat pengusir nyamuk mengandung DEET (Cameron dan Lorenz, 2013). Minyak esensial dari daun mint dapat digunakan sebagai antiseptik, pereda flu, mengatasi masalah pencernaan, mengurangi rasa sakit kepala, dan sebagai pengusir nyamuk yang efektif sekaligus meredakan bekas gigitan dan iritasi yang disebabkan oleh nyamuk (Curtis, Johnsons, dan Thomas, 2016).
Selain itu, berdasarkan studi yang dilaporkan oleh Acton (2013), ekstrak kulit jeruk mengandung 90\% d-limonene, yaitu zat yang telah terdaftar sebagai pengusir serangga, salah satunya pengusir nyamuk.

Dalam pelaksanaan kegiatan pengabdian masyarakat ini, masyarakat diberi pengetahuan mengenai bahaya penggunaan obat nyamuk sintetis terhadap kesehatan. Selain itu, masyarakat juga diberikan penyuluhan mengenai bahan alam yang dapat mengusir nyamuk serta diberi pelatihan untuk membuat lotion pengusir nyamuk berbahan dasar alami dari sereh, kulit jeruk dan juga daun mint sebagai alternatif pengusir nyamuk yang aman, efektif dan mudah diperoleh. Pemberian penyuluhan dan workshop ini bertujuan untuk meningkatkan pengetahuan masyarakat dalam hal pemilihan penggunaan obat nyamuk sintesis dan alami sebagai upaya pencegahan penyakit DBD. Harapannya, dengan memiliki pengetahuan dan ketrampilan yang benar akan obat pengusir nyamuk, jumlah penderita penyakit DBD di wilayah Pulomas Barat RW 11 akan dapat berkurang.

\section{METODE}

Kegiatan pengabdian kepada masyarakat ini diadakan di RW 11 Pulomas Barat, Kecamatan Pulogadung, Jakarta Timur, selama bulan April sampai dengan bulan Juli 2018. Mitra merupakan warga, bekerjasama dengan tim PKK dan Jumantik (Juru Pemantau Jentik) RW 11, Pulomas Barat, Jakarta Timur. Mitra dipilih karena faktor lokasinya yang dekat dengan kali Sunter dan waduk Pulomas, adanya kampung pemulung dengan timbunan sampah serta cukup tingginya angka kejadian penyakit DBD. Selain itu, lokasi mitra cukup dekat dengan lokasi pengabdi, yaitu sekitar $500 \mathrm{~m}$. Kegiatan ini dilakukan untuk membantu mengurangi angka kejadian DBD di daerah Pulomas Barat dengan cara 
Agnes Anania Triavika Sahamastuti, Elsabda Siratan, Theodore Ebenezer Leonard, Gisella Edny Tjugianto, Leonny Yulita Hartiadi, Istiqomah Agusta

Penyuluhan dan Workshop Obat Nyamuk Sintetis dan Alami Sebagai Tindakan Pencegahan DBD

memberikan penyuluhan untuk meningkatkan pengetahuan warga mengenai bahaya penggunaan obat nyamuk sintetis, bahan alami yang dapat digunakan untuk mengusir nyamuk, serta memberikan pelatihan pembuatan lotion pengusir nyamuk alami dari kulit jeruk, minyak atsiri sereh dan daun mint.

\section{Kegiatan Penyuluhan dan Pelatihan Kepada Masyarakat}

Proses penyuluhan dibagi menjadi 2 tahap, yaitu penyuluhan mengenai bahaya penggunaan obat nyamuk sintetis pada kesehatan dan penyuluhan mengenai bahan alami yang dapat mengusir nyamuk. Untuk mengetahui adanya peningkatan pengetahuan para partisipan, dilakukan pembagian kuesioner sebelum penyuluhan (pre-test) dan setelah penyuluhan (post-test). Indikator keberhasilan pelaksanaan penyuluhan adalah dengan adanya peningkatan nilai post-test para peserta dibandingkan dengan nilai pre-test sebelum penyuluhan.

Proses pelatihan pembuatan lotion pengusir nyamuk alami dilakukan setelah tahap penyuluhan selesai. Minyak atsiri yang digunakan adalah minyak atsiri sereh dan peppermint yang diperoleh dari Happy Green Garden ${ }^{\circledR}$, sedangkan minyak kulit jeruk diekstrak dari jeruk Sunkist Mesir dalam minyak biji anggur bermerek Borges®. Lotion yang digunakan sebagai basis adalah lotion yang tidak berbau atau mengandung parfum, yaitu Aveeno®. Lotion tersebut dibagi rata sebanyak 50 gram ke dalam silinder pot krim. Setiap pot dicampur dengan tiga bahan yang berbeda. Takaran yang digunakan adalah $5 \mathrm{~mL}$ untuk setiap bahan yang dicampurkan per pot lotion.

\section{Survey Penggunaan Lotion Pengusir Nyamuk Alami}

Satu bulan setelah pemberian pelatihan pembuatan lotion pengusir nyamuk alami dari minyak atsiri sereh, minyak atsiri peppermint dan minyak kulit jeruk, dilakukan survey terkait kepuasan penggunaan lotion tersebut. Survey diberikan kepada para partisipan yang sebelumnya datang menghadiri kegiatan pelatihan. Survey ini mencakup pendapat pengguna mengenai kelebihan dan kekurangan lotion pengusir nyamuk alami. Survey ini diadakan untuk melihat minat para peserta penyuluhan dalam pemakaian obat pengusir nyamuk alami yang telah dibuat

\section{HASIL DAN PEMBAHASAN}

Penyuluhan mengenai bahaya obat nyamuk sintetis berikut herbal alamiah berkhasiat mengusir nyamuk telah berhasil dihadiri oleh sekitar 37 partisipan dengan rentang umur berkisar dari $<16$ tahun sampai dengan $>45$ tahun bertempat di ruang SD. Mekarsari, Pulomas Barat, Kecamatan Pulogadung, Jakarta Timur. Penyuluhan ini sebagian besar dihadiri oleh anggota kelompok ibu-ibu PKK dan juga kelompok Jumantik di RW 11, Pulomas Barat. Kegiatan ini sendiri merupakan tahap lanjutan dari satu rangkaian kegiatan pengendalian demam berdarah dengue (DBD) di RW 11, Pulomas Barat. Kegiatan pengendalian DBD ini sengaja menargetkan kelompok ibu-ibu PKK dan kelompok Jumantik dengan pertimbangan bahwa kedua kelompok ini memiliki peran penting dalam pelaksanaan kegiatan-kegiatan pengendalian DBD, seperti $3 \mathrm{M}$ plus dan juga pengawasan jentik-jentik nyamuk di rumah para warga.

\section{Penyuluhan Bahaya Penggunaan Obat Nyamuk Sintetis dan Bahan Alami Pengusir Nyamuk}

Dalam penyuluhan ini dijabarkan dengan detil beberapa bahan kimia berbahaya yang terkandung didalam obat pengusir nyamuk sintetis, seperti Piretrina, Propoxur, DEET dan DDVP. Keempat jenis insektisida ini umum digunakan sebagai pengusir nyamuk rutin 
Agnes Anania Triavika Sahamastuti, Elsabda Siratan, Theodore Ebenezer Leonard, Gisella Edny Tjugianto, Leonny Yulita Hartiadi, Istiqomah Agusta

Penyuluhan dan Workshop Obat Nyamuk Sintetis dan Alami Sebagai Tindakan Pencegahan DBD

di dalam rumah dan terkandung pada obat nyamuk bakar, semprot maupun oles. Senyawa-senyawa ini berpotensi menimbulkan kanker, iritasi saluran pernafasan, maupun reaksi alergi lainnya (Briassoulis et al., 2001; Briassoulis et al., 2001; Agency, 2000). Setelah penyuluhan selesai, diadakan acara tanya jawab antara penyuluh dengan peserta. Sebagian besar pertanyaan yang diajukan adalah mengenai cara penggunaan yang obat pengusir nyamuk sintetis yang baik untuk meminimalkan efek samping yang dihasilkan.

Sebagai evaluasi peningkatan pengetahuan partisipan, kuesioner mengenai jenis bahan pengusir nyamuk yang sering dipakai diberikan kepada para peserta penyuluhan. Survey tentang penggunaan obat nyamuk sintetis di daerah warga sampai dengan saat ini belum pernah dilakukan. Padahal data tersebut dapat digunakan untuk membantu justifikasi angka kejadian penyakit DBD yang ada di daerah itu. Dari 37 responden, $96,8 \%$ adalah wanita, dengan tingkat pendidikan bervariasi, mulai dari SD $(16,1 \%)$, SLTP $(22,6 \%)$, SMA $(41,9 \%)$, S1 (12,9\%), dan S2-S3 (6,5\%). Sebanyak $32,3 \%$ dari jumlah keseluruhan responden pernah atau memiliki anggota keluarga yang pernah terjangkit penyakit DBD.

Berdasarkan hasil survey, diperoleh data bahwa sebagian besar peserta cenderung memilih lotion $(71 \%)$ sebagai jenis pengusir nyamuk yang sering dipakai sehari-hari (Gambar 1) dengan alasan sebagian besar adalah agar tidak digigit nyamuk, praktis, mudah dipakai, murah dan berbau harum. Hal ini memang sesuai dengan target pasar lotion pengusir nyamuk, yang cenderung lebih mudah dibawa, praktis digunakan dan murah dibandingkan dengan jenis pengusir nyamuk yang lain. Hasil yang diperoleh relevan dengan hasil survey yang diadakan oleh Wahyono and Oktarinda(2016) di DKI Jakarta dan Depok, yaitu bahwa jenis obat nyamuk yang sering digunakan oleh masyarakat adalah lotion.

$71 \%$ responden menggunakan obat nyamuk sebanyak 1 kali sehari, dan hanya 9,7\% yang menggunakan 2 kali sehari (Gambar 3). Hal ini menggambarkan keadaan masyarakat di daerah tersebut umum menggunakan obat pengusir nyamuk dengan frekuensi yang tidak terlalu sering. Umumnya para responden menggunakan obat pengusir nyamuk pada malam hari, dimana frekuensi gigitan nyamuk menjadi lebih sering.Meskipun dalam kasus DBD, nyamuk Aedes aegypti lebih aktif menggigit manusia pada siang hari, walaupun kadang kala juga menggigit di malam hari (Yasuno and Tonn, 1970).

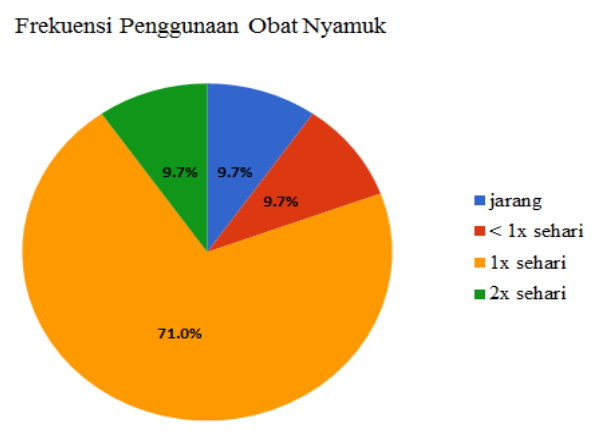

Gambar 1. Frekuensi Penggunaan Obat Nyamuk

Jenis Obat Nyamuk yang Dianggap Paling Efektif

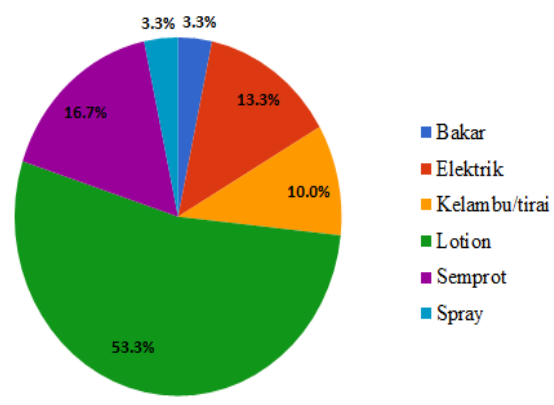

Gambar 2. Jenis Obat Nyamuk yang Dianggap Paling Efektif 
Agnes Anania Triavika Sahamastuti, Elsabda Siratan, Theodore Ebenezer Leonard, Gisella Edny Tjugianto, Leonny Yulita Hartiadi, Istiqomah Agusta

Penyuluhan dan Workshop Obat Nyamuk Sintetis dan Alami Sebagai Tindakan Pencegahan DBD

Berdasarkan hasil survey, diperoleh data bahwa setengah dari para responden percaya bahwa lotion merupakan jenis pengusir nyamuk yang paling efektif, diikuti dengan semprot, elektrik, kelambu, bakar dan spray (Gambar 2). Hal ini ternyata selaras dengan pemikiran bahwa lotion merupakan jenis pengusir nyamuk yang paling aman $(45,2 \%)$, sedangkan obat nyamuk bakar dan semprot adalah yang paling tidak aman (Gambar 3). Fakta ini tentu saja kurang sesuai, karena penggunaan kelambu/tirai yang merupakan pengusir nyamuk fisik lebih aman dibandingkan dengan penggunaan obat pengusir nyamuk kimiawi. Hal ini kemudian diperkuat oleh jawaban para responden bahwa kelambu/tirai tidak mengganggu kesehatan, sedangkan obat nyamuk bakar merupakan yang paling berbahaya bagi kesehatan (Gambar 4).

Jenis Obat Nyamuk yang Dianggap Paling Aman

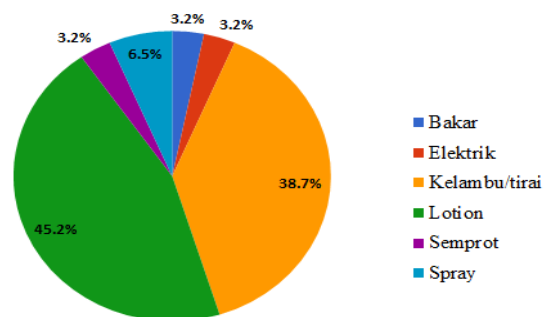

Gambar 3. Jenis Obat Nyamuk yang Dianggap Paling Aman

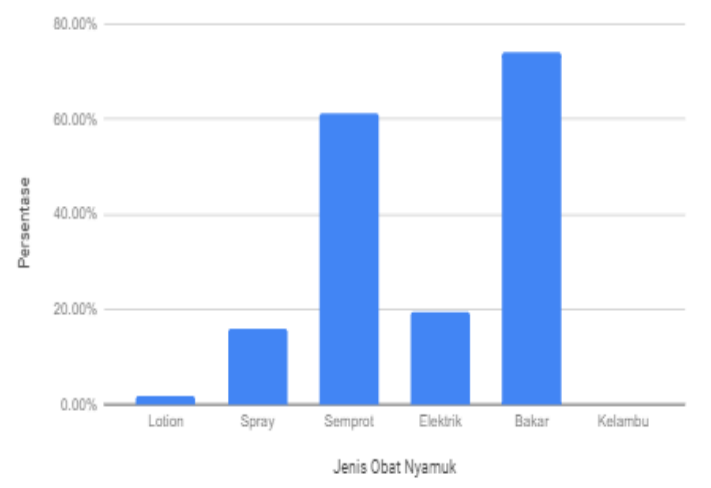

Gambar 5. Jenis Obat Nyamuk yang Dianggap Berbahaya Bagi Kesehatan
Penelitian serupa yang dilakukan oleh Wahyono dan Oktarinda (2016) di DKI Jakarta dan Depok juga memberikan hasil yang serupa, dimana masyarakat menganggap lotion sebagai obat nyamuk yang dianggap paling aman dan efektif. Hal inilah yang kemudian menyebabkan lotion paling diminati sebagai obat pengusir nyamuk.

Data yang diperoleh dari kuesioner tersebut dapat juga menggambarkan pengaruh iklan obat pengusir nyamuk di Indonesia. Sangat jarang dan hampir tidak adanya iklan mengenai anjuran penggunaan kelambu/tirai dibandingkan dengan obat pengusir nyamuk sintetis mengakibatkan kurangnya pemahaman masyarakat mengenai jenis pengusir nyamuk yang aman untuk digunakan dalam jangka waktu panjang. Sedangkan jawaban para responden mengenai lotion sebagai obat pengusir nyamuk yang paling aman kemungkinan besar didasarkan pada pengalaman pribadi responden yang menggunakan lotion pengusir nyamuk dalam jangka waktu tertentu dan tidak mengalami adanya gangguan kesehatan.

Dalam penyuluhan selanjutnya dibahas secara detail mengenai bahanbahan aktif beserta bukti-bukti ilmiah dari kulit jeruk, daun mint dan sereh sebagai pengusir nyamuk. Ketiga bahan ini dipilih berdasarkan tingkat keefektifan dan kemudahan memperolehnya di lingkungan sekitar masyarakat.

Pada akhir penyuluhan, para partisipan diberikan pelatihan mengenai pembuatan lotion pengusir nyamuk alami menggunakan minyak sereh, minyak peppermint dan minyak kulit jeruk.

Sediaan lotion pengusir nyamuk yang dilatihkan dalam penyuluhan ini menggunakan basis krim Aveeno ${ }^{\circledR}$ yang tidak berbau dan hipoalergenik. Lotion pengusir nyamuk yang dibuat mengandung $10 \%$ minyak esensial, berdasarkan data penelitian dari Oyedele et al (2002). Selain itu, pada konsentrasi 
Agnes Anania Triavika Sahamastuti, Elsabda Siratan, Theodore Ebenezer Leonard, Gisella Edny Tjugianto, Leonny Yulita Hartiadi, Istiqomah Agusta

Penyuluhan dan Workshop Obat Nyamuk Sintetis dan Alami Sebagai Tindakan Pencegahan DBD

minyak yang digunakan tidak merusak sistem emulsi dari lotion yang dihasilkan. Setiap partisipan kemudian membuat masing-masing lotion minyak sereh, minyak kulit jeruk dan minyak peppermint.

Sebagai bahan evaluasi, sebelum dan sesudah pemberian penyuluhan dan pelatihan, setiap partisipan diberikan pretest dan posttest mengenai bahan penyuluhan. Setelah penyuluhan diperoleh data peningkatan pengetahuan masyarakat mengenai bahaya obat nyamuk sintetis dan bahan alamiah berkhasiat mengusir nyamuk dibandingkan dengan sebelum penyuluhan. Sebanyak $29,7 \%$ peserta menjawab benar untuk kandungan bahan berbahaya didalam obat nyamuk sintetis, yaitu lebih dari dua kali lipat jumlah peserta yang menjawab benar pada pretest. Terdapat peningkatan sebanyak $6,5 \%$ untuk peserta yang menjawab benar mengenai bahaya obat nyamuk bakar setelah penyuluhan, $15 \%$ peningkatan untuk bahaya obat nyamuk spray dan $5,5 \%$ peningkatan untuk jenis-jenis herbal berkhasiat mengusir nyamuk. Seluruh peserta (100\%)mengetahui khasiat daun mint sebagai bahan pengusir nyamuk setelah penyuluhan. Sebanyak 91,7\% responden mengaku mengetahui cara membuat minyak kulit jeruk setelah penyuluhan, dibandingkan dengan hanya $22,6 \%$ responden sebelum penyuluhan. Seluruh peserta juga memilih menggunakan lotion pengusir nyamuk alami daripada sintetis setelah diberikan penyuluhan, meningkat dari hanya $66,7 \%$ sebelum penyuluhan.

Tabel 1. Persentase responden yang menjawab benar dari hasil pretest dan posttest

\begin{tabular}{cc}
\hline No & Pertanyaan \\
& $\begin{array}{c}\text { Persentase } \\
\text { responden yang } \\
\text { menjawab benar }\end{array}$ \\
\hline
\end{tabular}

\begin{tabular}{|c|c|c|c|}
\hline & & $\begin{array}{l}\text { Pre-test } \\
(\%)\end{array}$ & $\begin{array}{l}\text { Post } \\
\text {-test } \\
(\%)\end{array}$ \\
\hline 1 & $\begin{array}{l}\text { Apakah kandungan } \\
\text { berbahaya dari obat } \\
\text { nyamuk sintetis? }\end{array}$ & 12,9 & 29,7 \\
\hline 2 & $\begin{array}{l}\text { Sebutkan bahaya jenis } \\
\text { obat nyamuk bakar! }\end{array}$ & 93,5 & 100 \\
\hline 3 & $\begin{array}{l}\text { Sebutkan bahaya jenis } \\
\text { obat nyamuk spray! }\end{array}$ & 74,2 & 89,2 \\
\hline 4 & $\begin{array}{l}\text { Sebutkan bahan } \\
\text { alam herbal } \\
\text { berkhasiat mengusir } \\
\text { nyamuk! }\end{array}$ & 87,1 & 92,6 \\
\hline 5 & $\begin{array}{l}\text { Apakah daun mint } \\
\text { dapat mengusir } \\
\text { nyamuk? }\end{array}$ & 83,3 & 100 \\
\hline 6 & $\begin{array}{l}\text { Apakah anda tahu cara } \\
\text { pembuatan minyak } \\
\text { kulit jeruk? }\end{array}$ & 22,6 & 91,7 \\
\hline 7 & $\begin{array}{l}\text { Apakah anda tahu cara } \\
\text { pembuatan lotion } \\
\text { pengusir nyamuk dari } \\
\text { bahan herbal? }\end{array}$ & 3,3 & 91,7 \\
\hline 8 & $\begin{array}{l}\text { Apakah Anda memilih } \\
\text { lotion pengusir } \\
\text { nyamuk sintetis atau } \\
\text { alami? }\end{array}$ & $\begin{array}{l}\text { Alami } \\
(66,7 \%)\end{array}$ & $\begin{array}{l}\text { Ala } \\
\text { mi } \\
(100 \\
\%)\end{array}$ \\
\hline
\end{tabular}

\section{Survey Penggunaan Lotion Pengusir Nyamuk Alami}

Dua minggu setelah penyuluhan selesai, kepada responden yang sama diberikan kuesioner ulang mengenai penggunaan lotion pengusir nyamuk alamiah. Sebanyak 36,6\% responden mengaku menggunakan lotion minyak jeruk, 51,2\% menggunakan lotion minyak peppermint dan 12,2\% menggunakan lotion minyak sereh (Gambar 5). Umumnya para responden menggunakan lotion pengusir nyamuk alami dalam 
Agnes Anania Triavika Sahamastuti, Elsabda Siratan, Theodore Ebenezer Leonard, Gisella Edny Tjugianto, Leonny Yulita Hartiadi, Istiqomah Agusta

Penyuluhan dan Workshop Obat Nyamuk Sintetis dan Alami Sebagai Tindakan Pencegahan DBD

rentang waktu 4 hari sampai dengan 1 bulan.

\section{Jenis Lotion Pengusir Nyamuk}

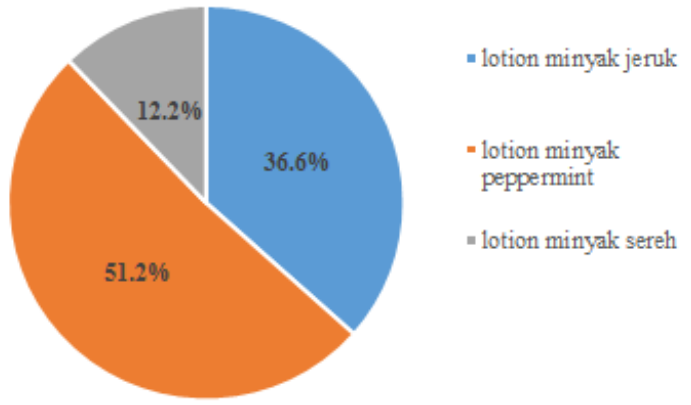

Gambar 5. Proporsi Lotion Pengusir Nyamuk yang Digunakan Oleh Responden

Dalam jangka waktu dua minggu, ternyata hanya sekitar $27,8 \%$ responden yang dapat mengingat cara pembuatan lotion pengusir nyamuk dan $54,2 \%$ responden yang dapat mengingat cara pembuatan minyak kulit jeruk. Hal ini disebabkan karena pelatihan yang diberikan masih dalam tahap kognitif, yaitu pemberian pengetahuan baru mengenai cara pembuatan lotion pengusir nyamuk, sehingga tidak banyak membekas dalam ingatan. Idealnya, untuk memperoleh keahlian tertentu, seseorang harus melewati tahap kognitif, asosiatif dan autonomi yang umumnya diperoleh melalui pelatihan terus-menerus (Tenison and Anderson, 2016).

Berdasarkan hasil survey, lotion minyak peppermint terpilih sebagai lotion pengusir nyamuk yang paling efektif, diikuti oleh lotion minyak kulit jeruk dan lotion minyak sereh (Gambar 6). Sedangkan, berdasarkan hasil review yang dilakukan oleh Maia dan Moore (2011), minyak sereh memiliki efektifitas yang paling tinggi dibandingkan dengan minyak peppermint dan minyak kulit jeruk. Bahkan citronella (kandungan dalam minyak sereh) telah banyak digunakan sebagai pengusir nyamuk alami dengan konsentrasi antara 5-10\%.
Perbedaan efektifitas ini mungkin disebabkan oleh mutu minyak esensial yang digunakan, atau efek placebo dari rasa dingin yang ditimbulkan oleh minyak peppermint.

Hampir seluruh responden mengaku tertarik menggunakan lotion pengusir nyamuk alami lagi setelah diberikan penyuluhan.

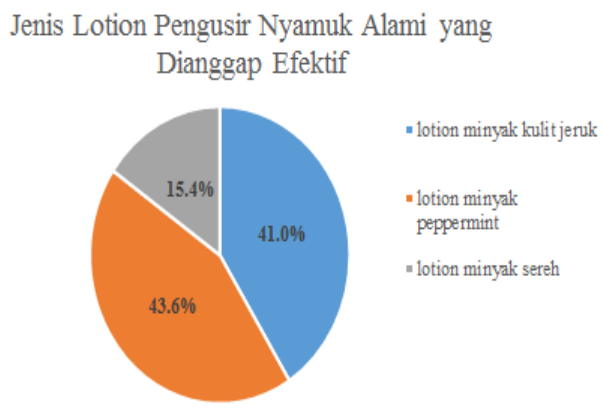

Gambar 6. Jenis Lotion Pengusir Nyamuk Alami yang Dianggap Paling Efektif Berdasarkan Hasil Survey

Dari hasil akhir survey, sebanyak $41,9 \%$ responden mengatakan bahwa aroma lotion cepat hilang, sedangkan 29\% mengatakan bahwa aromanya terlalu kuat, sehingga memberikan rasa kurang nyaman (Gambar 8). Hal ini sesuai dengan hasil review yang dilakukan oleh Lee (2018), yang menyatakan bahwa efektifitas esensial oil berkisar antara 30 menit sampai dengan 2 jam saja. Disisi lain, 36,8\% responden mengatakan bahwa lotion pengusir nyamuk alami memiliki aroma yang enak dihirup, dan 23,7\% mengatakan nyaman dipakai (Gambar $10)$. 
Agnes Anania Triavika Sahamastuti, Elsabda Siratan, Theodore Ebenezer Leonard, Gisella Edny Tjugianto, Leonny Yulita Hartiadi, Istiqomah Agusta

Penyuluhan dan Workshop Obat Nyamuk Sintetis dan Alami Sebagai Tindakan Pencegahan DBD

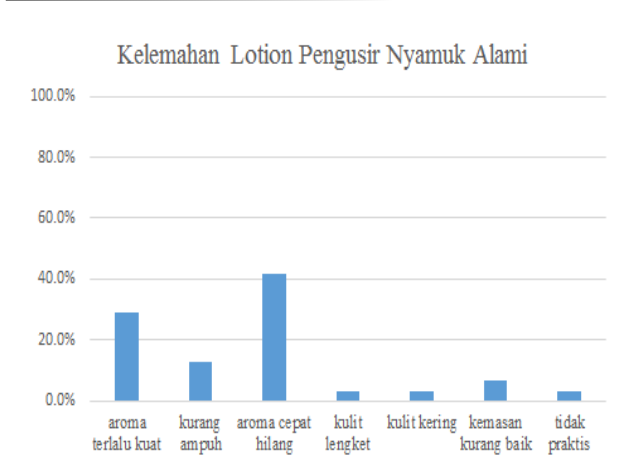

Gambar 7. Kelemahan Lotion Pengusir Nyamuk Alami Berdasarkan Data Survey

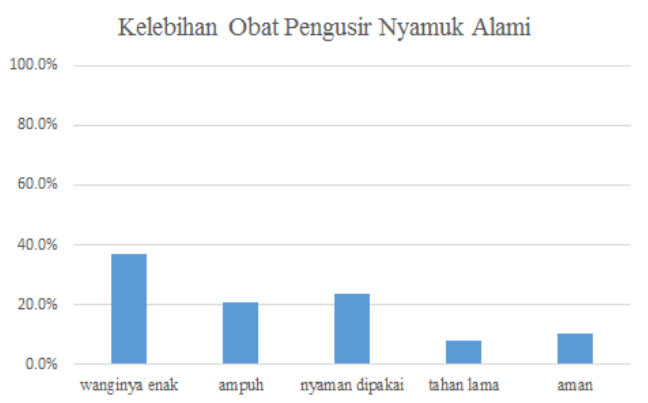

Gambar 8. Kelebihan Obat Pengusir Nyamuk Alami Berdasarkan Data Survey

Berdasarkan keseluruhan data yang diperoleh, kegiatan pengabdian kepada masyarakat ini telah berhasil memberikan peningkatan pengetahuan masyarakat mengenai bahaya obat nyamuk sintetis, sekaligus memberikan solusi nyata melalui pelatihan pembuatan lotion pengusir nyamuk alami. Lotion yang dihasilkan tidak memiliki jangka waktu pengusiran nyamuk yang panjang dikarenakan bahan alami yang digunakan, sehingga memerlukan penggunaan terus menerus setiap 2-3 jam. Namun demikian, lotion pengusir nyamuk alami ini cenderung lebih aman digunakan dibandingkan dengan lotion pengusir nyamuk dari bahan sintetis. Kegiatan ini diharapkan dapat berdampak pada penurunan angka kejadian penyakit DBD di daerah warga RW 11, Pulomas Barat, Jakarta Timur.

\section{SIMPULAN}

Kegiatan penyuluhan mengenai bahaya obat nyamuk sintetis bagi kesehatan dan bahan alami yang dapat mengusir nyamuk serta pelatihan pembuatan lotion pengusir nyamuk berbahan dasar alami menunjukkan adanya peningkatan tingkat pengetahuan para partisipan yang terdiri dari warga RW 11 beserta ibu-ibu PKK dan kader Jumantik di Pulomas Barat, Jakarta Timur. Berdasarkan hasil survey, lotion pengusir nyamuk alami memiliki kelebihan dengan wangi yang enak dan ampuh, sedangkan kekurangannya adalah aromanya cepat hilang dan terlalu kuat. Kegiatan pengabdian ini diharapkan akan mendorong warga untuk membuat lotion anti nyamuk berbahan alami sendiri sebagai bagian dari kegiatan pencegahan DBD.

\section{UCAPAN TERIMAKASIH}

Para penulis dan pelaksana kegiatan pengabdian masyarakat mengucapkan terimakasih kepada Ristekdikti atas bantuan hibah pendanaan Program Kemitraan Masyarakat (PKM) tahun 2018. Ucapan terimakasih juga disampaikan kepada para pihak yang telah membantu seluruh pelaksanaan kegiatan PKM.

\section{DAFTAR PUSTAKA}

Acton, Q. A. (2013). PesticidesAdvances in Research and Application. US: Scholarly Editions.

Ansari, M. A., Vasudevan, P., Tandon, M., \& Razdan, R. K. (2000). Larvicidal And Mosquito Repellent Action Of Peppermint (Mentha Piperita) Oil. Bioresource Technology, 71(3), 267-271. 
Agnes Anania Triavika Sahamastuti, Elsabda Siratan, Theodore Ebenezer Leonard, Gisella Edny Tjugianto, Leonny Yulita Hartiadi, Istiqomah Agusta Penyuluhan dan Workshop Obat Nyamuk Sintetis dan Alami Sebagai Tindakan Pencegahan DBD

Antwi, F. B., Shama, L. M., \& Peterson, R. K. (2008). Risk Assessments For The Insect Repellents DEET And Picaridin. Regulatory Toxicology and Pharmacology, 51(1), 31-36.

Binukumar, B. K., \& Gill, K. D. (2010). Cellular and Molecular Mechanisms of Dichlorvos Neurotoxiciy: Cholinergic, Noncholinergic, Cell Signaling, Gene Expression and Therapeutic Aspects. Indian Journal of Experimental Biology, 48, 697709.

Briassoulis, G., Narlioglou, M., \& Hatzis, T. (2001). Toxic Encephalopathy Associated With Use Of DEET Insect Repellents: A Case Analysis Of Its Toxicity In Children. Human \& Experimental Toxicology, 20, 814.

Cameron, M. M., \& Lorenz, L. M. (2013). Biological and Environmental Control of Disease Vectors. UK: $\mathrm{CAB}$ International.

Chillemi, M., \& Chillemi, S. (2017). The Complete Guide to Natural Healing: A Natural Approach to Healing the Body and Maintaining Optimal Health Using Herbal Supplements, Vitamins, Minerals, Fruits, Vegetables and Alternative Medicine. USA: Lulu Press.

Cid, M. G., Loria, D., \& Matos, E. (1990). Genotoxicity Of Pesticide Propoxur And Its Nitroso Derivative, NOPropoxur, On Human Lymphocytes In Vitro. Mutation Research, 232, 45-48.

Curtis, S., Johnson, F., \& Thomas, P. (2016). Essential Oils: All-natural remedies and recipes for your mind, body and home. UK: Dorling Kindersley Limited.

Deletre, E., Chandre, F., Barkman, B., Menut, C., \& Martin, T. (2016).
Naturally Occurring Bioactive Compounds From Four Repellent Essential Oils Against Bemisia Tabaci Whiteflies. Pest Management Science, 72(1), 179-189.

Ford, R. B., \& Mazzaferro, E. (2011). Kirk \& Bistner's Handbook of Veterinary Procedures and Emergency Treatment-E-Book, Section I: Emergency Care. Elsevier Health Sciences.

Gillett, J. W., Harr, J. R., Lindstrom, F. T., Mount, D. A., Clair, A. D. S., \& Weber, L. J. (1972). Evaluation of human health hazards on use of dichlorvos (DDVP), especially in resin strips. Residue reviews. New York: Springer.

Govere, J., Durrheim, D. N., Du, N. T., Hunt, R. H., \& Coetzee, M. (2000). Local plants as repellents against Anopheles arabiensis, in Mpumalanga Province, South Africa. The Central African Journal of Medicine, 46(8), 213-216.

Hendra, I.S., \& Mila M. (2004). Demam Berdarah; Perawatan di Rumah \& Rumah Sakit + Menu. Jakarta: Puspa Swara, Anggota IKAPI.

Kamatou, G. P., Vermaak, I., Viljoen, A. M., \& Lawrence, B. M. (2013). Menthol: A Simple Monoterpene With Remarkable Biological Properties. Phytochemistry, 96, 1525.

Kementerian Kesehatan Republik Indonesia. (2016). Profil Kesehatan Indonesia $2015 . \quad$ Jakarta: Kementerian Kesehatan Republik Indonesia

Kompas.com. (2016). Ini Tiga Kecamatan dengan Kasus DBD Tertinggi di Jakarta.https://megapolitan.kompas.c om/read/2016/02/12/16150851/Ini.Ti ga.Kecamatan.dengan.Kasus.DBD.T 
Agnes Anania Triavika Sahamastuti, Elsabda Siratan, Theodore Ebenezer Leonard, Gisella Edny Tjugianto, Leonny Yulita Hartiadi, Istiqomah Agusta Penyuluhan dan Workshop Obat Nyamuk Sintetis dan Alami Sebagai Tindakan Pencegahan DBD

ertinggi.di.Jakarta. Diunduh tanggal 6 Juli 2017.

Lee, M. Y. (2018). Essential oils as repellents against arthropods. Biomed Research International, 2018, 1-9.

Maia, M. F., \& Moore, S. J. (2011). Plantbased insect repellents: a review of their efficacy, development and testing. Malaria Journal, 10(1), S11.

Merdeka.com. (2016). Wabah DBD di Jakarta meningkat 2 kali lipat, Januari ada 611 kasus. https://www.merdeka.com/jakarta/wa bah-dbd-di-jakarta-meningkat-2-kalilipat-januari-ada-611-kasus.html. Diunduh tanggal 13 Agustus 2018.

Munif, A., Musadad, D. A., \& Kasnodihardjo. (2013). Model Intervensi Pengendalian Demam Berdarah Dengue di Kabupaten Indramayu, Jawa Barat. Jurnal Ekologi Kesehatan, 12(4), 253-268.

Murugan, K., Kumar, P. M., Kovendan, K., Amerasan, D., Subrmaniam, J., \& Hwang, J. S. (2012). Larvicidal, pupicidal, repellent and adulticidal activity of Citrus sinensis orange peel extract against Anopheles stephensi, Aedes aegypti and Culex quinquefasciatus (Diptera: Culicidae). Parasitology Research, 111(4), 1757-1769.

Oyedele, A. O., Gbolade, A. A., Sosan, M. B., \& Adewoyin, F. B. (2002). Formulation Of An Effective Mosquito-Repellent Topical Product From Lemongrass Oil. Phytomedicine, 9(3), 259.

Roberts, G. (2014). Dealing with Dengue: Diagnosing, Treating, and Recovering from Dengue Fever. Thailand: Thailand Reirement Press.

Saillenfait, A. M., Ndiaye, D., \& Sabaté, J. P. (2015). Pyrethroids: exposure and health effects-an update.
International Journal Of Hygiene And Environmental Health, 218(3), 281-292.

Suharmiati, M. 2007. Tanaman Obat \& Ramuan Tradisional untuk Mengatasi Demam Berdarah Dengue. Indonesia: AgroMedia.

Tenison, C., \& Anderson, J. R. (2016). Modeling the distinct phases of skill acquisition. Journal of Experimental Psychology: Learning, Memory and Cognition, 42(5), 749.

Traboulsi, A. F., El-Haj, S., Tueni, M., Taoubi, K., Nader, N. A., \& Mrad, A. (2005). Repellency and toxicity of aromatic plant extracts against the mosquito Culex pipiens molestus (Diptera: Culicidae). Pest Management Science: Formerly Pesticide Science, 61(6), 597-604.

United States Environmental Protection Agency. (2000). Propoxur (Baygon). https://www.epa.gov/sites/production /files/2016-

09/documents/propoxur.pdf. Diunduh tanggal 6 Juli 2017.

United States Environmental Protection Agency. (2000). Dichlorvos. https://www.epa.gov/sites/production /files/2016-

09/documents/dichlorvos.pdf.

Diunduh tanggal 6 Juli 2017.

Wahyono, T. Y. M., \& MW, Oktarinda. (2016). Penggunaan Obat Nyamuk dan Pencegahan DemamBerdarah di DKI Jakarta dan Depok. Jurnal Epidemiologi Kesehatan Indonesia, 1(1), 35-40.

Yasunno, M. \& Tonn, R.J. (1970). A study of biting habits of Aedes aegypti in Bangkok, Thailand. Bull World Health Organ, 43 (2), 319-325. 